\title{
FAKTOR YANG MEMPENGARUHI KEPUTUSAN MAHASISWA BERWISATA KE LUAR NEGERI
}

\author{
I Putu David Adi Saputra \\ Universitas Udayana \\ Email: davidsaputra22@gmail.com \\ Made Antara \\ Universitas Udayana \\ Email: antara_unud@yahoo.com \\ I Nyoman Sudiarta \\ Universitas Udayana \\ Email: sudiarta.nyoman@yahoo.co.id
}

\begin{abstract}
Tourism and hospitality is one of the largest service industries in the world that has an influence on global economic growth. Various factors can influence a person to travel There is a phenomenon that shows the increasing number of tourist visits abroad. This indicates that the need to travel by Indonesian tourists is getting higher. Indonesian tourists who travel both home and abroad consist of various ages and occupations. The purpose of this study was to analyze the pull and push factors that influence the decision of Bali tourism students to travel abroad. This study uses survey research methods with a total of 130 respondents. Researchers used factor analysis techniques and were processed using the IBM SPSS V.26 for Windows program. The results of the analysis of the results included that the motivation that became the push factors of Bali tourism students traveling abroad was to want to show prestige or lifestyle, while the motivation that became the pull factors of Bali tourism students traveling abroad was because the location, products, and services in the tourist destination area that can be accessed easily.
\end{abstract}

Keywords: Push Factors, Pull Factors, Travel Decisions.

\section{Pendahuluan}

Pariwisata dan perhotelan adalah salah satu industri jasa terbesar di dunia yang mempunyai pengaruh terhadap pertumbuhan ekonomi global dan memicu sebagian besar negara di dunia untuk membuat industri pariwisata sebagai sektor 
terkemuka untuk menghasilkan devisa negara dan menggerakan perekonomian negara tersebut. (Bagyono, 2012:3). Yakup (2019) menegaskan bahwa pertumbuhan ekonomi dipengaruhi oleh pariwisata secara positif dan signifikan. Demikian juga sebalikanya bahwa pertumbuhan ekonomi mempunyai pengaruh positif dan signifikan terhadap pariwisata.

Penelitian yang telah dilakukan oleh Booking.com menemukan adanya hubungan antara wisata dan kewarganegaraan seseorang. Berdasarkan siaran pers Booking.com yang diterima KompasTravel (2019) disampaikan bahwa motivasi utama berwisata bagi sebagian besar wisatawan adalah untuk bersantai. Motivasi utama untuk berwisata. Hal lain yang menjadi motivasi berwisata orang Indonesia adalah menghabiskan waktu bersama keluarga, mengeksplorasi sensasi dan pengalaman yang tidak mungkin didapat di rumah, dan yang unik adalah mengunjungi tempat-tempat baru yang belum dikunjugi oleh teman.

Penelitian yang dilakukan oleh Booking.com (2018), menemukan bahwa gaya berwisata bisa dipengaruhi oleh kewarganegaraan seseorang. Terdapat lima motivasi berwisata teratas oleh wisatawan global adalah untuk bersantai, untuk beristirahat, mendapatkan pengalaman yang tidak bisa didapatkan di rumah, menjelajah sebanyak mungkin, dan bebas melakukan apa yang diinginkan. Bagi wisatawan Indonesia terdapat lima motivasi berwisata teratas, yaitu untuk beristirahat, meluangkan waktu untuk bersantai, menghabiskan waktu bersama keluarga, menemukan sensasi dan kegembiraan, dan pengalaman yang tidak bisa dimiliki di rumah.

Azahari, Ketua Ikatan Cendekiawan Pariwisata Indonesia (ICPI), dalam wawancaranya dengan Berita Tagar (2019) melaporkan bahwa tren kenaikan penduduk Indonesia yang berwisata ke luar negeri setiap tahunnya mengalami pertumbuhan yang cukup signifikan. Salah satu alasan yang mempengaruhi hal tersebut adalah harga tiket pesawat rute domestik yang terbilang mahal, sehingga 
wisatawan yang berasal dari Indonesia lebih memilih untuk berlibur ke luar negeri dengan biaya tiket yang relatif terjangkau.

Bisnis Wisata (2019) melaporkan bahwa berdasarkan data dari Asosiasi Travel Agent Indonesia, terdapat peningkatan sebesar 10 persen atas pertumbuhan wisatawan Indonesia yang melakukan wisata ke luar negeri dengan jumlah sekitar 10,7 juta wisatawan di tahun 2019. Negara-negara favorit wisatawan Indonesia adalah Singapura, Malaysia, Thailand, Jepang, dan Korea Selatan. Dalam penelitiaan Santoso et al. (2018) didapat tujuh faktor yang mempengaruhi motivasi wisatawan generasi muda saat berwisata di Yogyakarta, yaitu wisata budaya, relaksasi, bersenangsenang, menikmati alam, bertualang, bepergian dengan keluarga, dan meningkatkan status sosial. Hasil penelitian Sudiarta et al. (2014) menunjukkan bahwa persepsi distribusi keadilan, prosedur, dan interaksi mempunyai pengaruh yang positif dan signifikan terhadap kepuasan pasca pemulihan oleh wisatawan yang berkunjung ke Bali.

Hasil penelitian Sari et al. (2018) menyatakan bahwa motivasi wisatawan muda yang berkunjung ke destinasi wisata minat khusus dipengaruhi oleh tujuh faktor, yaitu pendukung berwisata, novelty, ego and family enhancement, leisure time, aktualisasi diri, wish-fulfillment, dan interaksi sosial. Faktor pendukung berwisata merupakan faktor motivasi yang paling mendominasi. Hasil penelitian Dewi et al. (2017) menyatakankan bahwa faktor pendorong yang paling utama bagi orang Bali untuk berwisata ke luar negeri adalah adalah kesempatan belajar, diikuti oleh bersantai dan bermain. Faktor penarik yang paling utama bagi orang Bali berwisata ke luar negeri adalah faktor budaya, diikuti oleh lingkungan alam dan rekreasi dan layanan atraksi. Menurut hasil penelitian Antara dan Prameswari (2018) menunjukan bahwa ada tiga faktor utama faktor pendorong wisatawan berkunjung ke destinasi wisata di Bali yaitu status dan pengembangan diri, budaya, dan hubungan interpersonal, sedangkan faktor penariknya adalah masyarakat, suasana dan iklim, 
keamanan dan kebersihan, dan kesempatan unutk melaksanakan kegiatan di luar ruangan

Hal yang membedakan penelitian ini dan penelitian sebelumnya adalah peneliti ingin lebih menyoroti generasi muda yang diwakili oleh mahasiswa pariwisata program Diploma IV dan Sarjana strata satu yang sedang dan atau melanjutkan studinya di Bali yang melakukan wisata ke luar negeri. Rumusan masalah dalam penelitian ini adalah 1) Apa saja faktor pendorong dominan yang mempengaruhi keputusan mahasiswa pariwisata Bali berwisata ke luar negeri? 2) Apa saja faktor penarik dominan yang mempengaruhi keputusan mahasiswa pariwisata Bali berwisata ke luar negeri?

\section{Teori dan Metode Penelitian}

Penelitian ini menggunakan teori motivasi berwisata. Menurut Pitana dan Gayatri (2005), motivasi merupakan yang faktor penting bagi calon wisatawan memutuskan tempat yang akan dikunjungi. Motivasi wisatawan adalah salah satu faktor yang harus diperhatikan untuk meningkatkan industri pariwisata suatu daerah. Setiap wisatawan yang akan mengunjungi destinasi mempunyai motivasi yang tidak sama, sehingga setiap pengelola destinasi di suatu daerah perlu untuk memahami motivasi wisatawan karena berguna untuk meningkatkan industri dan menarik wisatawan untuk mempbuat keputusan pembelian atau keputusan mengunjungi tempat wisata. Sebelum melakukan perjalanan, seorang calon wisatawan akan melakukan sebuah proses pemikiran terlebih dahulu, untuk sampai pada suatu keputusan, mengenai kapan akan melakukan perjalanan, berapa lama, dimana, bagaimana, dan lain-lain. Proses pengambilan keputusan ini sangat penting untuk pengembangan pariwisata, melibatkan berbagai faktor yang mempengaruhi keputusan dan faktor-faktor tersebut dapat mempengaruhi proses promosi wisata. Pemahaman yang jelas tentang proses pengambilan keputusan tidak hanya penting sebagai dasar promosi, tetapi juga penting dalam perencanaan produk dan dalam 
menentukan segmen pasar atau tujuan pemasaran. Hal ini semakin penting di dalam situasi yang semakin kompetitif, terutama karena pasar mulai menjadi sangat tersegmentasi.

Metode yang digunakan dalam penelitian ini adalah metode kuantitatif yang didukung oleh data-data kualitatif dengan rancangan penelitian survei yang melibatkan para mahasiswa sekolah pariwisata di Bali yang berkunjung keluar negeri. Lokasi penelitian adalah di beberapa kampus pariwisata yang terdapat di Bali, yaitu: Universitas Udayana, Universitas Dhyana Pura, Universitas Triatma Mulya Bali, Sekolah Tinggi Pariwisata Bali, Politeknik Negeri Bali, dan Institut Pariwisata dan Bisnis Internasional. Penelitian ini merupakan penelitian ekplanatori. Penelitian eksplanatori adalah penelitian yang bertujuan menjelaskan kedudukan variabel yang diteliti dan hubungan antara variabel yang satu dengan variabel lainnya (Sugiyono, 2012:21). Peneliti menggunakan jenis data data kuantitatif dan data kualitatif.

Rekomendasi ukuran sampel untuk analisis faktor adalah 100 atau lebih. Jumlah anggota sampel ditentukan berdasarkan hasil perhitungan sampel minimum. Rumus untuk menentukan sampel, yaitu jumlah indikator variabel observasi dikalikan 5 (lima), 10 (sepuluh) 15 (lima belas) atau 20 (dua puluh) (Hair, et al, 2006:9899). Jumlah total indikator dalam penelitian ini adalah sebanyak 26. Supaya jumlah responden dapat ditentukan, maka jumlah total indikator dikalikan 5 (lima), sehingga hasil perhitungannya sebagai berikut: 26 × $5=130$ responden. Jadi diperlukan 130 responden sebagai sampel. 


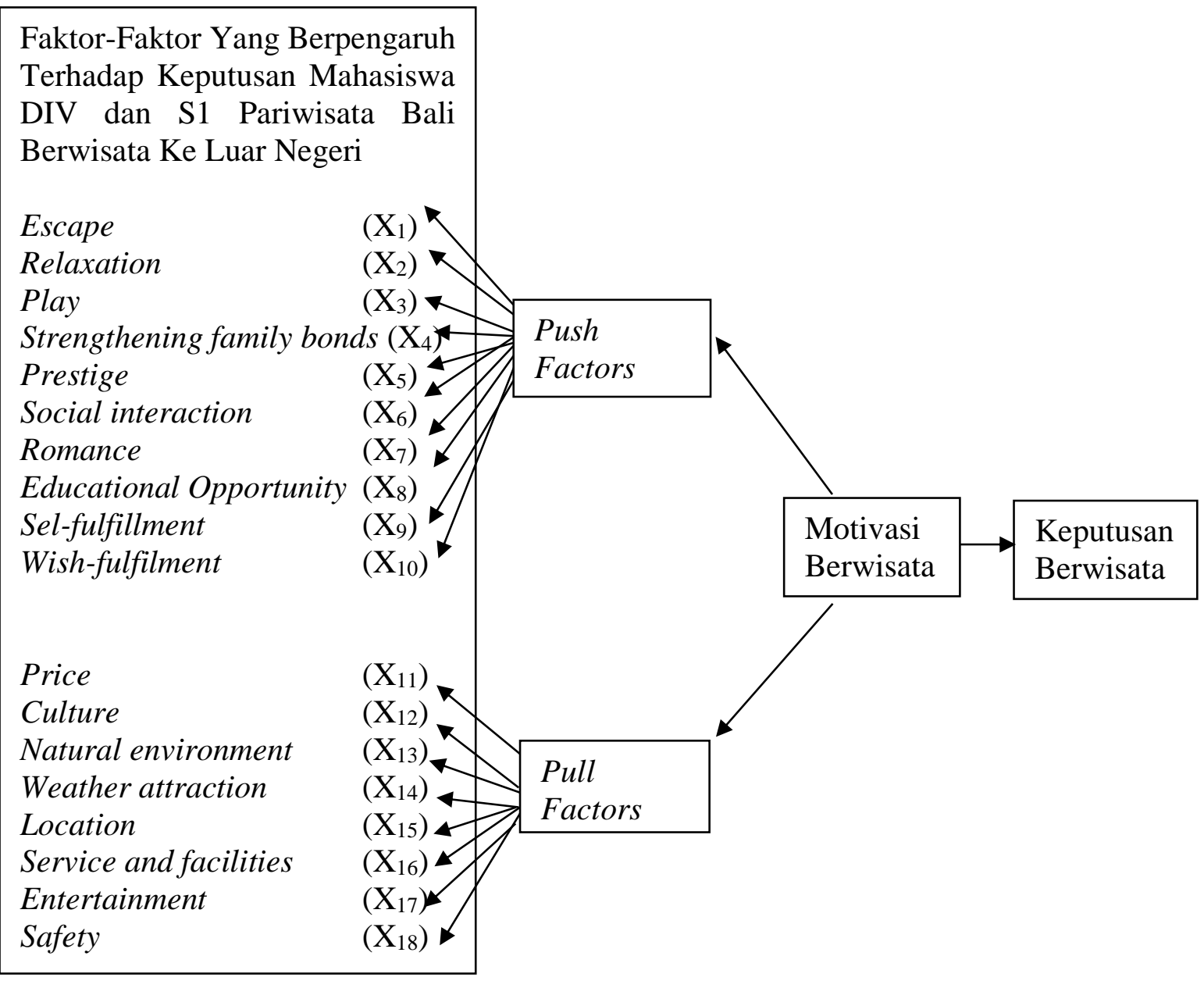

Gambar 1. Kerangka Berpikir dan Konsep Penelitian

Skala Likert yang digunakan dalam penelitian ini adalah untuk mengukur sikap, pendapat, dan persepsi seseorang atau sekelompok orang tentang suatu fenomena sosial.. Peneliti menggunakan teknik analisis faktor dan diolah dengan menggunakan program IBM SPSS V.26 for Windows. Menurut Hair et al dalam Widarjono (2010:240), analisis faktor adalah teknik analisis multivariate, yang mempunyai model hubungan variabel yang bersifat interdependensi. Metode ini terdiri atas model hubungan model independen dan model hubungan interdependensi. 


\section{Analisis Statistik Karakteristik Responden}

Karakteristik responden yang diambil dari para mahasiswa pariwisata di Bali yang berwisata ke luar negeri dapat diuraikan sebagai berikut: Berdasarkan umur mahasiswa yang menjadi responden disebutkan bahwa mayoritas responden berumur 20 tahun berjumlah 39 orang atau 30 persen. Hal ini menunjukan bahwa umur produktif mahasiswa yang melakukan wisata ke luar negeri berumur 18 sampai 20 tahun, dimana mereka sudah dapat secara mandiri melakukan perjalanan ke luar negeri. Lebih banyak responden yang berjenis kelamin wanita yaitu berjumlah 82 orang atau 63 persen, sisanya berjenis kelamin pria berjumlah 48 orang atau 37 persen. Hal ini menunjukan bahwa kebutuhan wisata adalah kebutuhan semua orang, baik pria maupun wanita, namun responden wanita terlihat lebih dominan berwisata ke luar negeri dibandingkan responden pria. Berdasarkan asal daerah, responden yang berasal dari Denpasar paling banyak yaitu 46 orang atau 35 persen, diikuti dari Gianyar berjumlah 22 orang atau 17 persen, dari Badung sebanyak 10 orang atau 8 persen, dari Tabanan sebanyak 8 orang atau 6 persen, dari Pontianak sebanyak 6 orang atau 5 persen, dari Surabaya sebanyak 4 orang atau 3 persen, dari Singaraja, Klungkung, Jember, dan Jakarta masing-masing 3 orang atau 2 persen, dari Ubud, Nusa Lembongan, Medan, Bangli masing-masing sebanyak 2 orang atau 2 persen, serta dari Surakarta, Sulawesi, Semarang, Sampit, Ruteng, Pasuruan, Maluku Utara, Malang, Labuan Bajo, Karangasem, Jembrana, Buleleng, Blitar, dan Batam masingmasing 1 orang atau 1 persen. Hal ini menunjukan bahwa responden paling banyak berasal dari Bali dan diikuti responden yang berasal dari luar Bali, karena para responden tersebut melanjutkan studi mereka di salah satu sekolah pariwisata dan perhotelan di Bali.

Berdasarkan asal perguruan tinggi bahwa responden dari IPB Internasional sebanyak 51 orang atau 39 persen, dari Poltekpar sebanyak 43 orang atau 33 persen, dari Unud sebanyak 14 orang atau 11 persen, dari PNB sebanyak 12 orang atau 9 persen, dari Untrim sebanyak 7 orang atau 3 persen, dan dari Undhira sebanyak 3 
orang atau 2 persen. Hal ini sesuai dengan jumlah sampel yang diperlukan dari masing-masing asal sekolah responden tersebut. Berdasarkan negara yang dikunjungi oleh responden yang paling banyak adalah Singapura sebanyak 45 orang atau 35 persen, Thailand sebanyak 25 orang atau 19 persen, Jepang sebanyak 17 orang atau 13 persen, Amerika Serikat sebanyak 11 orang atau 8 persen, diikuti Korea Selatan sebanyak 8 orang atau 6 persen, Australia dan Malaysia masing-masing sebanyak 6 orang atau 5 persen, China dan Hongkong sebanyak 2 persen, serta Belanda, Dubai, Italia, London, Perancis, Roma, dan Spanyol masing-masing sebanyak 1 orang atau 1 persen. Hal ini menunjukan bahwa negara di kawasan Asia adalah tempat wisata yang diminati oleh para responden. Lokasi dan daerah wisata yang dekat dan menarik membuat mayoritas para responden berwisata di negara kawasan Asia. Berdasarkan jumlah kunjungan ke luar negeri yang sebanyak 1 kali ada 93 orang atau 72 persen, lebih dari 3 kali sebanyak 19 orang atau 15 persen, 2 kali sebanyak 12 orang atau 9 persen, serta 3 kali sebanyak 6 orang atau 5 persen. Hal ini menunjukan bahwa mayoritas responden baru pertama kali melakukan wisata ke luar negeri atau mempunyai pengalaman pertama kali berwisata ke luar negeri.

Berdasarkan pengeluaran biaya yang lebih dari Rp 8.000.000,- berjumlah 46 orang atau 35 persen, yang pengeluarannya dari Rp 6.100.000,- sampai dengan Rp 8.000.000,- berjumlah 35 orang atau 27 persen, yang pengeluarannya dari Rp 2.000.000,- sampai dengan Rp 4.000.000,- berjumlah 31 orang atau 24 persen, serta yang pengeluarannya dari Rp 4.100.000,- sampai dengan Rp 6.000.000,- berjumlah 18 orang atau 14 persen. Hal ini menunjukan bahwa pengeluaran selama berwisata cukup besar, bisa disebabkan karena lamanya menginap dan biaya akomodasi, makan, dan pembelian cindera mata. Berdasarkan tujuan utama mahasiswa berkunjung untuk rekreasi/ berlibur, yaitu sebanyak 83 orang atau 64 persen, mencari pengalaman baru sebanyak 17 orang atau 13 persen, melakukan studi tour sebanyak 15 orang atau 12 persen, mengunjungi keluarga/teman sebanyak 7 orang atau 5 persen, melanjutkan studi dan training sebanyak 2 orang atau 2 persen, serta yang 
tujuan utamanya kuliner, lomba, magang, dan menonton pertandingan masingmasing sebanyak 1 orang atau 1 persen. Hal ini menunjukan bahwa mayoritas responden mempunyai tujuan utama untuk berlibur/rekreasi untuk melepaskan kepenatan dan rutinitas sehari-hari serta mencari pengalaman yang baru. Di luar negeri para responden mendapatkan hal-hal yang baru dan menarik.

Berdasarkan asal sumber informasi bagi responden, media sosial/internet sebanyak 62 orang atau 48 persen, disusul informasi dari kerabat/teman sebanyak 35 orang atau 27 persen, dari sekolah sebanyak 17 orang atau 13 persen, dari agen wisata sebanyak 15 orang atau 12 persen, serta dari orang tua sebanyak 1 orang atau 1 persen. Hal ini menunjukan bahwa media sosial/internet dan teman/kerabat sangat efektif untuk meningkatkan jumlah mahasiswa yang berwisata ke luar negeri. Begitu mudah para responden mendapatkan informasi dari media sosial/internet karena masingmasing mereka mempunyai ponsel yang sekarang menjadi kebutuhan pokok para responden. Pihak agen wisata pun berusaha memunculkan iklan daerah tujuan wisata di luar negeri yang menarik bagi para responden. Berdasarkan lama kunjungan responden, disebutkan bahwa 49 orang atau 38 persen mempunyai lama kunjungan selama 3-4 hari, yang lama kunjungannya 5-6 hari dan lebih dari 6 hari masing-masing sebanyak 29 orang atau 22 persen, serta sebanyak 23 orang atau 18 persen yang lama kunjungannya 1-2 hari saja. Hal ini menunjukan bahwa para responden mempunyai waktu setidaknya 1-2 hari untuk tinggal dan menikmati wisata di luar negeri. Mayoritas para responden dalam penelitian ini mempunyai lama kunjungan 3-4 hari.

Karakeristik responden berdasarkan lama menginap adalah 5 orang atau 35 persen yang lama menginapnya lebih dari 4 hari 3 malam, yang lama menginapnya 3 hari 2 malam sebanyak 30 orang atau 23 persen, yang lama menginapnya 3 hari 2 malam sebanyak 29 orang atau 22 persen, serta sebanyak 26 orang atau 20 persen yang lama menginapnya 2 hari 1 malam. Hal ini menunjukan bahwa para responden mempunyai waktu setidaknya 2 hari 1 malam untuk menginap di hotel atau tempat akomodasi lainnya dan menikmati wisata di luar negeri. Mayoritas para responden 
menginap lebih dari 4 hari 3 malam. Berdasarkan destinasi yang disukai, wisata alam disukai oleh 54 orang atau 42 persen, sebanyak 42 orang atau 32 persen yang menyukai destinasi wisata budaya, disusul sebanyak 33 orang atau 25 persen yang menyukai destinasi wisata buatan, serta hanya 1 orang atau 1 persen yang menyukai destinasi wisata kuliner. Hal ini menunjukan bahwa para responden lebih menyukai destinasi alam, budaya, dan wisata buatan. Ragam destinasi tersebut dalam dinikmati di daerah tujuan wisata di luar negeri khususnya di kawasan Asia. Berdasarkan berapa kali responden berwisata dlam satu tahun, diperoleh hasil bahwa 75 orang atau 58 persen berwisata sekali dalam setahun, sebanyak 26 orang atau 20 persen yang berwisata 2 kali dalam setahun, serta 29 orang atau 22 persen yang berwisata lebih dari 2 kali dalm setahun. Hal ini menunjukan bahwa mayoritas responden minimal berwisata sekali dan setahun. Hal ini disebabkan sebagai seorang mahasiswa pariwisata dan perhotelan mereka mempunyai waktu yang harus dibagi antara belajar, melakukan Daily Worker, dan kemungkinan bekerja sambil kuliah sehingga minimal mereka dapat berwisata sekali dalam setahun.

Berdasarkan perencanaan responden untuk pergi ke destinasi wisata, sebagian besar, yaitu sebanyak 120 orang atau 92 persen responden merencanakan untuk pergi ke destinasi wisata dan sebanyak 10 orang saja atau 8 persen yang pergi ke destinasi wisata tanpa rencana sebelumnya. Hal ini menunjukan bahwa para responden benarbenar merencakan kepergian mereka untuk berwisata atau ke destinasi dikarenan sebagai mahasiswa pariwisata dan perhotelan mereka mempunyaiwaktu yang sangat padat untuk dibagi antara belajar, melakukan Daily Worker, dan kemungkinan bekerja sambil kuliah sehingga segala sesuatunya harus diperhitungakan dan direncakan secara matang. Berdasarkan dengan siapa responden berwisata, menunjukkan bahwa sebagian besar, yaitu sebanyak 76 orang atau 58 persen responden berwisata dengan keluarga, disusul sebanyak 43 orang atau 33 persen yang berwisata dengan teman, serta sebanyak 11 orang saja atau 8 persen yang pergi ke destinasi wisata sendiri tanpa ada yang menemani. Data menunjukan bahwa mayoritas responden berwisata 
bersama keluarga dan teman. Hal ini bisa dipahami karena sebagai mahasiswa dan diumur yang masih muda mereka lebih senang berwisata secara berkelompok, baik bersama keluarga maupun teman.

Analisis Statistik Kuantitatif Faktor Penarik dan Pendorong Yang Mempengaruhi Keputusan Mahasisiwa Pariwisata Bali Berisata Ke Luar Negeri

Penilaian responden terhadap faktor pendorong yang mempengaruhi keputusan mahasiswa pariwisata dapat dilihat pada table berikut ini:

Tabel 1. Penilaian responden terhadap faktor pendorong yang mempengaruhi keputusan mahasiswa pariwisata

\begin{tabular}{|c|c|c|c|c|c|c|c|}
\hline \multirow[b]{2}{*}{ Kode } & \multirow{2}{*}{ Indikator } & \multicolumn{5}{|c|}{ Jawaban (orang) } & \multirow{2}{*}{ Rerata } \\
\hline & & STS & TS & KS & $S$ & SS & \\
\hline PH1 & Escape & 4 & 0 & 18 & 46 & 62 & 4,2 \\
\hline PH2 & Escape & 6 & 8 & 43 & 41 & 32 & 3,7 \\
\hline PH3 & Relaxation & 6 & 2 & 21 & 54 & 47 & 4,0 \\
\hline PH4 & Relaxation & 4 & 0 & 14 & 48 & 64 & 4,3 \\
\hline PH5 & Play & 3 & 4 & 31 & 40 & 52 & 4,0 \\
\hline PH6 & Play & 30 & 27 & 38 & 21 & 14 & 2,7 \\
\hline PH7 & $\begin{array}{l}\text { Strengthening } \\
\text { family bonds }\end{array}$ & 34 & 20 & 39 & 23 & 14 & 2,7 \\
\hline PH8 & $\begin{array}{l}\text { Strengthening } \\
\text { family bonds }\end{array}$ & 6 & 5 & 41 & 44 & 34 & 3,7 \\
\hline PH9 & Prestige & 8 & 6 & 39 & 48 & 29 & 3,6 \\
\hline PH10 & Prestige & 3 & 6 & 46 & 39 & 36 & 3,8 \\
\hline PH11 & $\begin{array}{l}\text { Social } \\
\text { interaction }\end{array}$ & 7 & 2 & 31 & 45 & 45 & 3,9 \\
\hline
\end{tabular}




\begin{tabular}{|l|l|l|l|l|l|l|l|}
\hline \multirow{2}{*}{ Indikator } & \multicolumn{4}{|l|}{ Jawaban (orang) } & \multirow{2}{*}{ Rerata } \\
\cline { 3 - 7 } & STS & TS & KS & S & SS & \\
\hline PH12 & $\begin{array}{l}\text { Social } \\
\text { interaction }\end{array}$ & 3 & 0 & 20 & 55 & 52 & 4,2 \\
\hline PH13 & Romance & 3 & 0 & 8 & 47 & 72 & 4,4 \\
\hline PH14 & $\begin{array}{l}\text { Educational } \\
\text { opportunity }\end{array}$ & 2 & 3 & 12 & 46 & 67 & 4,3 \\
\hline PH15 & $\begin{array}{l}\text { Educational } \\
\text { opportunity }\end{array}$ & 2 & 1 & 11 & 45 & 71 & 4,4 \\
\hline PH16 & $\begin{array}{l}\text { Self fulfilment } \\
\text { PH17 }\end{array}$ & 4 & 7 & 33 & 44 & 42 & 3,9 \\
\hline PH18 & Welf fulfilment & 4 & 4 & 25 & 52 & 45 & 4,0 \\
\hline & Wish fulfilment & 2 & 1 & 13 & 29 & 85 & 4,5 \\
\hline
\end{tabular}

Sumber : Hasil Penelitian 2021.

Berdasarkan Tabel 1 dapat diketahui faktor pendorong diukur menggunakan sepuluh indikator yaitu escape, relaxation, play strenthening family bond, prestige, social interaction romance, educational opportunity self fullfilment, wish fulfilment memiliki nilai rata-rata sebesar 3,9 yang artinya responden memiliki faktor pendorong dengan kategori tinggi. Indikator yang memiliki nilai rata-rata tertinggi ditunjukkan oleh educational opportunity sebesar 4,37 kemudian disusul oleh indikator relaxation sebesar 4,16, social interaction sebesar 4,05, wish fulfilment sebesar 3,93, kemudian prestige sebesar 3,70 dan terendah pada indikator play sebesar 3,37.

Penilaian responden terhadap faktor penarik yang mempengaruhi keputusan mahasiswa pariwisata Bali berwisata keluar negeri dapat dilihat pada berikut ini: 
Tabel 2. Penilaian responden terhadap faktor penarik yang mempengaruhi keputusan mahasiswa pariwisata Bali berwisata keluar negeri

\begin{tabular}{|c|c|c|c|c|c|c|c|}
\hline \multirow[b]{2}{*}{ Kode } & \multirow{2}{*}{ Indikator } & \multicolumn{5}{|c|}{ Jawaban (orang) } & \multirow{2}{*}{ Rerata } \\
\hline & & STS & TS & KS & $S$ & SS & \\
\hline PL1 & Price & 0 & 2 & 21 & 27 & 80 & 4,42 \\
\hline PL2 & Culture & 0 & 2 & 17 & 48 & 63 & 4,32 \\
\hline PL3 & $\begin{array}{l}\text { Natural environment and } \\
\text { weather attraction }\end{array}$ & 1 & 2 & 25 & 42 & 60 & 4,22 \\
\hline PL4 & Location & 1 & 2 & 34 & 44 & 49 & 4,06 \\
\hline PL5 & Location & 0 & 2 & 20 & 46 & 62 & 4,29 \\
\hline PL6 & Service and facilities & 0 & 0 & 18 & 46 & 66 & 4,37 \\
\hline PL7 & $\begin{array}{l}\text { Entertainment and } \\
\text { relaxation }\end{array}$ & 2 & 5 & 22 & 42 & 59 & 4,16 \\
\hline PL8 & Safety & 0 & 1 & 17 & 47 & 65 & 4,35 \\
\hline & Rata-rata & & & & & & 4,28 \\
\hline
\end{tabular}

Sumber : Hasil Penelitian 2021

Berdasarkan Tabel 2 dapat diketahui faktor penarik diukur menggunakan tujuh indikator yaitu price, culture, natural environment and weather attraction, location, service and facilities, entertainment and relaxation, safety memiliki nilai rata-rata sebesar 4,28 yang artinya responden memiliki faktor penarik dengan kategori sangat tinggi. Indikator yang memiliki nilai rata-rata tertinggi ditunjukkan oleh wish fulfilment 4,42, kemudian location sebesar 4,37, safety sebesar 4,35, price sebesar 4,32, location sebesar 4,18, sedangkan natural environment and weather attraction mempunyai nilai terendah sebesar 4,06. 


\section{Simpulan dan Saran}

Berdasarkan hasil penelitian maka dapat disimpulkan bahwa 1) faktor pendorong (push factors) dominan mahasiswa pariwisata Bali berwisata ke luar negeri adalah ingin menunjukkan gengsi atau gaya hidup. 2) faktor penarik (pull factors) dominan mahasiswa pariwisata Bali berwisata ke luar negeri adalah karena daerah lokasi, produk, dan layanan di daerah tujuan wisata yang dapat diakses dengan mudah. Rekomendasi dari penelitian yang telah dilakukan sangat diperlukan untuk bahan pertimbangan bagi: 1) Pihak kampus/perguruan tinggi supaya dapat membuat program pengenalan akan budaya lain melalui study tour, pertukaran mahasiswa, magang atau training ke luar negeri, dan short course. Hal ini dapat dilakukan dengan cara bekerja sama dengan pihak hotel atau sekolah di luar negeri, sehingga para mahasiswa secara tidak langsung dapat kesempatan berkunjung bahkan berwisata ke luar negeri. 2) Pihak agen wisata membuat program berwisata ke luar negeri dengan harga yang terjangkau dalam satu paket tertentu sehingga banyak kawula muda khususnya mahasiswa pariwisata dapat berwisata ke luar negeri. 3) Para mahasiswa pariwisata supaya rajin menyisihkan uangnya dan mencari informasi terkait wisata di luar negeri, sehingga mereka dapat melakukan wisata ke luar negeri setidaknya sekali dalam setahun, baik secara mandiri atau secara berkelompok. 4) Penelitian di masa mendatang perlu melakukan penelitian ulang untuk mendapatkan hasil yang konsisten dan menambahkan variabel dan indikator yang lebih banyak.

\section{Ucapan Terima Kasih}

Penulis menyampaikan ucapan terima kasih dan penghargaan yang setinggitingginya kepada Prof. Dr. Ir. Made Antara, MS selaku pembimbing utama dan Dr. I Nyoman Sudiarta, S.E., M.Par.selaku pembimbing pendamping yang telah dengan sabar dan penuh pengertian memberikan bimbingan, arahan, semangat dan saran selama proses penyelesaian tulisan ini. 


\section{Profil Penulis}

I Putu David Adi Saputra adalah alumus Program Studi Magister Kajian Pariwisata Universitas Udayana. Ia menyelesaikan Program Strata 1 Sastra Inggris di Universitas Cipta Wacana Malang pada tahun 2003 dan pada tahun 2015 melanjutkan Program Magister Kajian Pariwisata di Universitas Udayana dan mengajar di IPB Internasional.

Made Antara adalah Guru besar fakultas pertanian Universitas Udayana Denpasar. Saat ini beliau mengajar dibeberapa fakultas dan program studi seperti Jurusan Sosial Ekonomi Pertanian Falkultas pertanian (PS.Agribisnis), Program Studi Magister Pariwisata, Program Doktor Pariwisata, Program Program Magister Ilmu Lingkungan dan Program Doktor Kajian Budaya.

I Nyoman Sudiarta adalah Dosen Fakultas Pariwisata di Universitas Udayana. Meraih Gelar Doktor (S3) di Universitas Udayana pada tahun 2015. Meraih Gelar Magister Pariwisata pada tahun 2004. Meraih Gelar Sarjana (S1) di Sekolah Tinggi Ilmu Manajemen Indonesia Handayani pada tahun 2002. 